\title{
DETRÁS DE SU MIRADA, UN MUNDO ${ }^{1}$
}

\author{
María Teresa Arias Bautista ${ }^{2}$
}

Tenía los ojos chiquititos, inexplicablemente prietos. Se le habían quedado pegados a las puntadas que las agujas, manejadas por sus diestras manos, diseñaron sobre las telas día tras día, noche tras noche. Tenía los ojos chiquititos, encogidos por las lágrimas derramadas aunque hiciera mucho tiempo que no lloraba porque poco a poco le fueron faltando las horas y las ganas. Se le había secado el alma entre los hilos y la almohada.

Un día, un raro día de confidencias, dejó volar la mirada. Sus pequeños ojos aletearon como las alas de una mariposa perdida en la niebla. Entre la maraña de las distancias emergió su pasado y preñada de amargura me ofreció unas pinceladas del retrato de su vida.

De chica, de muy chica, rompía el hielo de los baldes del corral de su casa del pueblo para poder fregar los platos. Su madre no quería estropearse las manos y ella era la encargada de hacerlo.

Lamentablemente sus recuerdos de infancia tenían que ver con una experiencia y esta se alejaba con mucho del imaginario al que, generalmente, quien más y quien menos permanece atado. Las madres ¡ay!, por más que se diga, no todas las madres son iguales. No todas las madres se quedan sin el mejor bocado, destierran los mejores sueños para mantenerse en vela, o destrozan sus manos en duros trabajos hasta que les sangran o se les llenan de callos...

\footnotetext{
${ }^{1}$ Fecha de recepción: 29/04/2013

Fecha de aceptación: 30/04/2013

${ }^{2}$ Licenciada en Historia Medieval, María Teresa Arias Bautista es autora de numerosas publicaciones sobre temas relacionados con la historia, el feminismo y la historia de las mujeres de las que podemos destacar Violencias y mujeres en la Edad Media Castellana, y Barraganas y Concubinas en la España Medieval. Entra en el mundo literario en 2009 con la novela La aventura ultramarina de Flora Van Meerck a la que sigue La aventura ultramarina de Isabel Sendales; $\square$ ogigias@ hotmail.com.
} 
Por eso, en la paradoja del ser y el deber ser naufragaron sus expectativas y se hundieron sus sueños de niña. Sus recuerdos eran ásperos y aún le hacían sufrir. Apenas cariños, apenas mimos, atravesaban los espacios de su memoria aunque los hubiera habido; ni juegos, ni amigas... Solo el lebrillo, la loza y el daño que le causara el agua helada la acompañaban. Se la veía zozobrar en las remembranzas de los quehaceres de aquella casa pegada a sus calcetines y a sus enaguas.

Contemplé silenciosa y acongojada cómo niñez y adolescencia se le apiñaban en la cara y le estrechaban aún más la ranura de aquellos ojitos con los que percibía un mundo que le ofreció pocos afectos. Suspiró y volvió al hilo de su relato. El siguiente recuerdo que puso sobre la mesa era muy posterior.

La familia se trasladó a Madrid como lo hicieran tantas otras en las épocas teñidas por la escasez y la penuria producida por el desgarro fratricida de la guerra. Como tantas otras mujeres de formación nula o básica eligió la aguja para sustentarse. Sus ojillos adquirieron un brillo especial al recordar los años que tal vez hubieron sido los mejores de su vida. La juventud se inmola en el sinsentido de la brevedad de la sonrisa fácil, las quimeras y los ensueños.

Aún no había cumplido los treinta cuando conoció a Mariano. La enamoró. Pensó, como cualquier muchacha educada en el cuento del príncipe azul, que él redimiría su destino con el beso del despertar. Vana ilusión. Duró poco. Pronto él se cansó de la cotidianidad y buscó el intenso sentir provocado por la incertidumbre de lo desconocido, de lo nuevo, de lo diferente...

Mariano trabajaba con ahínco. Mucho más de lo esperado pero sus sudores no se derramaban sobre su casa. Sus risas, sus caricias, sus regalos no los disfrutaba su esposa, sino mujeres que vendían los favores de sus cuerpos atrapadas en la extrema necesidad. Ella, acuciada por las carencias, tuvo que volver a enhebrar las agujas, cortar las telas y coser para las vecinas.

Su semblante, casi siempre pálido, se vistió de gris mientras revivía instantes dolorosísimos que se desgranaban entre sus dientes y se despeñaban en el vacío del silencio que nos envolvía a ambas, teñidos por la desolación y la amargura no desterrada. La boca apretada, las manos apretadas, los ojos hincados en el quicio de la puerta... 
-Vivíamos con la madre de Mariano... Ella nunca me apoyó. Yo me acostaba porque no quería ni verle y ella se levantaba para prepararle la cena cuando volvía harto de revolcarse con la puta de turno...

Su suegra, a quien también conocí, era una mujer transida por su propia desdicha. La vida no le había dejado más que a su hijo y ella era incapaz de ver sus desidias. Cómplice, quizás sin quererlo, disculpaba las faltas de su vástago y le cubría de atenciones dejando a su esposa en evidencia.

La madre volcaba un cariño desmedido sobre quien no debería haber sido el único receptor del mismo pero que, sin duda, resultaba la mejor de las pócimas contra su propio yermo. La madre lo hacía mal. La madre apoyaba al mal marido y ella se iba viendo asediada por un número interminable de sentimientos que se le agolpaban en el corazón hasta dejarla sin aliento. Le apremiaba la ira, la pena, el desamparo, la angustia, la mentira y el oprobio de compartir a su hombre con cualquiera...

Entre los hilos y las lágrimas, entre caricias obligadas en el silencio de la noche, vaciadas de amor, cargadas de miserias y de olores a otros cuerpos, se quedó embarazada. Con el dolor ceñido a la cintura y a su alma parió a su hijo, lo amamantó y se perdió en las ternuras de su crianza.

Tales experiencias, por muy sublimes que fueran, no le impidieron ser presa de la náusea en la presencia de un mal hombre. Llegó un momento en que no fue capaz de calentar la cama de quien venía de yacer con otras sin importarle el precio o el destino de los hijos que pudieran nacer de aquellos ilícitos acoplamientos. Sin embargo, sí se afanaba en engendrar en ella más hijos legítimos, tal y como ordenaba el ridículo mandamiento.

Todo se rompió. La rabia, la impotencia y el asco le dictaron los siguientes pasos. Pasos imprudentes bajo la mirada artera de una sociedad pacata, consentidora de la doble moral y que seguía sustentando los pilares de sus estructuras inconmovibles sobre la cacareada devoción de las madres, el recato de las doncellas y el callado, reverente y servil silencio de las esposas.

Un buen día cogió a su hijo en brazos y sus escasas pertenencias que cabían en una maleta y apareció en la casa de su padre y de su madre, que no hacía tanto había abandonado con los ojos preñados de ilusión y de esperanza. 
La recibieron con el disgusto en el semblante y el rechazo en el corazón. La recibieron porque no había más remedio y porque no eran tan pérfidos como para llegar a los extremos de la infamia que otros cometían al arrojar de su lado una parte de sí mismos que se hallaba atrapada y desvalida.

Su decisión hubo de pagarla cara, se lamentó con la voz desgarrada por una congoja interna omnipresente. Su decisión la pagó con la fuente inagotable de sus ojos que fueron encogiendo atrapados en el pañuelo y la escasa luz bajo la que, puntada tras puntada, daba forma de blusa, vestido o falda, a los metros interminables de las más diversas telas.

La vida para sí misma, aquella con la que ella había soñado, acabó por cerrarse a cualquier atisbo de posibilidad. Años y años los pasó amagada bajo el flexo, en el chiscón exiguo de la portería que la cobijaba.

Día o noche, lo mismo le daba. Para ella el día o la noche se confundían en el interior de un cuartucho sin ventana. Día o noche se le enredaban en el entendimiento y en las manos cuando la apremiaban para entregar una prenda. Día o noche, que tanto daban, trasmutaba, cual alquimista en la redoma, la labor por el sustento propio y de su hijo, por medicinas, libros o cuadernos para el colegio, por un balón, un pantalón, unos zapatos o una prenda de abrigo.

Poco a poco se fue arrugando. Imperceptiblemente se fue arrugando. Se le arrugaron las manos, se le arrugaron los ojos y, sobre todo, se le arrugó el sentimiento. Dejó de ser capaz de llorar, o de apenarse, o de mostrar la más mínima generosidad con nadie; ni siquiera con quienes, aún a costa de su cerrazón, se prodigaron con ella. No supo compartir al hijo, no supo disfrutar del nieto. No supo, no pudo, o no quiso exponer el terciopelo de su corazón ajado a los posibles nuevos embates de la existencia.

Se fue quedando sola con su amargura. Se fue quedando a oscuras en el espesor de su desesperanza. El tiempo le pasó y no supo, no pudo, o no quiso darse una oportunidad y dársela a quienes la rodeaban. Murió desierta, perdida en sus soledades, con los ojos marchitos, la mirada perdida y las manos vacías.

A Matilde, un recuerdo inhóspito en mi mirada. 